\title{
Intratesticular varicocele: a rare cause of male factor infertility
}

\author{
Ekta Dhamija, Chandan J Das, Abdul Razik
}

Department of Radiodiagnosis, All India Institute of Medical Sciences, New Delhi, India

Correspondence to Dr Chandan J Das, dascj@yahoo.com

Accepted 22 February 2018

\section{DESCRIPTION}

A 27-year-old man who presented to the urology outpatient department of our hospital with primary infertility was referred for scrotal ultrasonography (USG). He had no scrotal pain, prior sexually transmitted diseases, scrotal trauma or surgery. Physical examination and blood investigations were normal. Semen analysis showed oligospermia (count of 10 million $/ \mathrm{mL}$ ) with a large fraction $(>50 \%)$ of immotile sperms. B-mode USG revealed normal-sized bilateral testicles; however, the left testis showed multiple hypoechoic testicular lesions along with minimal fluid in the scrotal sac (figure 1A). The intratesticular lesions were homogeneous in size and diffusely scattered throughout the left testis, radiating towards the mediastinum testis. All the lesions demonstrated spontaneous colour flow on Doppler imaging, which identified these lesions as dilated intratesticular veins (figure 1B). The imaging findings were consistent with intratesticular varicocele (ITV). No dilated vascular channels suggestive of extratesticular varicocele (ETV) were seen in the extratesticular soft tissue or along the spermatic cord. The patient was advised surgery which he refused.

ITV is a rare entity with incidence of $1.3 \%-2 \%$ in contrast to the much more common ETV, which occurs in 15\%-20\% of men. ${ }^{1}$ Most of the literature on ITV has been in the form of case reports or anecdotal case series. Pain has been documented as the most common presenting complaint (46\%), followed by infertility (16\%-21\%). ${ }^{2}$ While most of the authors depicted left testicular involvement, Das et al showed no such predilection in their study of 25 cases. $^{2}$ The fact that majority $(72 \%)$ of ITV are associated with ipsilateral ETV has led to the hypothesis of common underlying pathophysiology. Hence, similar treatment techniques have been opted for both ETV and ITV with effective outcomes.

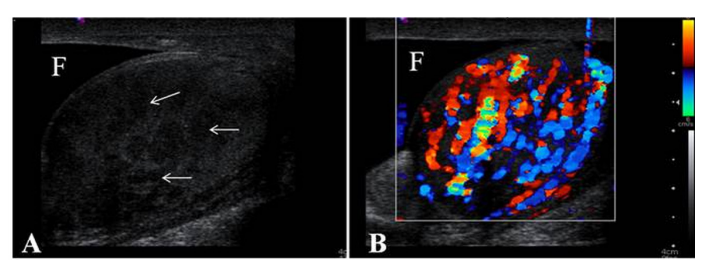

Figure 1 (A) Longitudinal ultrasound (US) scan of the left testis shows multiple intratesticular tubular hypoechoic lesions (white arrows) of similar size. Minimal fluid is also seen in the scrotal sac (F). (B) Colour Doppler US scan shows marked colour filling within the tubular structures suggesting them to be dilated veins.

\section{Learning points}

- Intratesticular varicocele (ITV) is a rare cause of male factor infertility and is entirely a sonographic diagnosis.

- On ultrasonography, any dilated intratesticular venous structure showing reflux on Valsalva manoeuvre should be diagnosed as ITV.

- Early diagnosis is critical since prompt surgery results in excellent outcome. Once testicular atrophy sets in, chances of fertility diminishes.

On USG, ITVs are seen as cystic or tubular anechoic channels $(>3 \mathrm{~mm}$ in size) radiating towards the mediastinum testis and showing prompt vascularity on colour Doppler. Secondary testicular atrophy is often present. Any intratesticular venous structure showing reflux on Valsalva manoeuvre should be considered as ITV, irrespective of the size. Anechoic cystic and hypoechoic lesions within the testis may represent tubular ectasia of rete testis, focal infection, haematoma or neoplasm. The characteristic imaging findings of spontaneous venous flow on colour Doppler and Valsalva manoeuvre determine the diagnosis of ITV and exclude other possible differentials. Patients with ITV are treated with surgical varicocelectomy or percutaneous embolisation. Adolescents with ITV should be treated with surgery as there is a higher risk of increasing testicular atrophy with time. ${ }^{3}$

Contributors ED, CJD: conception and design of the study. ED, CJD, AR: literature review and analysis, drafting. ED, CJD, AR: editing and approval of the final version.

Funding This research received no specific grant from any funding agency in the public, commercial or not-for-profit sectors.

Competing interests None declared.

\section{Patient consent Obtained.}

Provenance and peer review Not commissioned; externally peer reviewed.

(C) BMJ Publishing Group Ltd (unless otherwise stated in the text of the article) 2018. All rights reserved. No commercial use is permitted unless otherwise expressly granted.

\section{REFERENCES}

1 Kessler A, Meirsdorf S, Graif M, et al. Intratesticular varicocele: gray scale and color Doppler sonographic appearance. J Ultrasound Med 2005;24:1711-6.

Razik A. BMJ Case Rep

Published Online First:

[please include Day Month

Year]. doi:10.1136/bcr-2018

224547
2 Das KM, Prasad K, Szmigielski W, et al. Intratesticular varicocele: evaluation using conventional and Doppler sonography. AJR Am J Roentgenol 1999;173:1079-83.

3 MacLachlan LS, Nees SN, Fast AM, et al. Intratesticular varicoceles: are they significant? J Pediatr Urol 2013;9:851-5. 
Copyright 2018 BMJ Publishing Group. All rights reserved. For permission to reuse any of this content visit http://group.bmj.com/group/rights-licensing/permissions.

BMJ Case Report Fellows may re-use this article for personal use and teaching without any further permission.

Become a Fellow of BMJ Case Reports today and you can:

- Submit as many cases as you like

- Enjoy fast sympathetic peer review and rapid publication of accepted articles

Access all the published articles

- Re-use any of the published material for personal use and teaching without further permission

For information on Institutional Fellowships contact consortiasales@bmjgroup.com

Visit casereports.bmj.com for more articles like this and to become a Fellow 